\title{
"As Gay as Any Gypsy Caravan": Grant Wood and the Queer Pastoral at the Stone City Art Colony
}

\section{CHRISTOPHER HOMMERDING}

AT THE CLOSE OF THE SUMMER of 1932, the Christian Science Monitor ran a relatively lengthy piece on a moderately sized art colony in the tiny village of Stone City, Iowa. Located some 25 miles northeast of Cedar Rapids and just several miles outside of the nearby town of Anamosa, the virtual ghost town of Stone City was, in the early 1930s, experiencing a unique kind of rebirth. Earlier that summer, the sleepy village nestled in a corner of the winding Wapsipinicon River awoke, not to the explosive sounds of limestone quarrying, which had been the town's sole source of industry in the nineteenth century, but to the more peaceful and pensive sound of brush on canvas. This was the Stone City Art Colony and School-the first of its kind the Midwest. ${ }^{1}$

The research and writing of this article was graciously funded by a research grant
from the State Historical Society of Iowa. Special thanks go to Marvin Bergman,
Kristy Raine, and Sue Taylor for providing contacts and source leads. My grat-
itude also extends to the librarians and archivists, including David McCartney
at the University of Iowa and Becki Plunkett at the State Historical Society of
Iowa, who aided me in locating and using materials for this project in Iowa.
Thanks also to Tripp Evans and the anonymous readers who provided exten-
sive feedback on a draft of the article. Finally, special appreciation goes to Jim
Hommerding and Jenn Ehalt for accompanying me on an initial sightseeing and
fact-finding mission in eastern Iowa; they also made wonderful models for our
own rendition of Wood's American Gothic. I dedicate this paper to my mother,
Karen Hommerding, who sadly passed away while this project was still in its
early stages. THE ANNALS OF IOWA 73 (Fall 2015). @ The State Historical Society of Iowa, 2015. 
To proclaim its discovery of a troop of artists camped out on an Iowa hillside in the summer of 1932, the Christian Science Monitor opened with a headline that - for present-day audiences - might seem a bit provocative. Focusing on the colony's housing challenges, the periodical declared, "Iowa Artists Live in Ice Carts as Gay as Any Gypsy Caravan." Indeed, housing for the hundred or so colony participants was in short supply in the tiny village. The bulk of the colony was located near the crest of a hill overlooking the village as it straddles the Wapsipinicon River. There the colonists planted their artistic flag on the former estate owned by nineteenth-century quarrying mogul John Aloysius Green. The sturdy stone buildings Green left behind - an ice house, barn, water tower, and, most elaborate of all, the "Green mansion" itself-served as a combination of studio, gallery, and instructional and living space. In the large Green mansion, female colonists roomed on the second floor, while male colonists bunked upstairs in the attic. The men who did not fit in the attic or could not afford the rooming costs pitched camp nearby in tents, or as its most famous resident, Grant Wood, did -in old ice wagons hauled from Cedar Rapids to serve as temporary shelter. ${ }^{2}$

Grant Wood, the Iowa-born artist who just two years earlier had made a name for himself and the art movement known as Regionalism with his now famous work, American Gothic, was the faculty director in 1932 and lived in one of ten ice wagons high above the village. ${ }^{3}$ Helping to shape the Christian Science Monitor's portrayal of the encampment as a gypsy caravan, Wood painted the outside of his wagon with a sweeping pastoral landscape in what would become his familiar style-fantastical scenes of sensually curving hillsides and farmscapes done in sharp, clearly

1. "Iowa Artists Live in Ice Carts as Gay as Any Gypsy Caravan," Christian Science Monitor, 8/25/1932 [special thanks to Kristy Raine for sharing this article with me]; Joan Muyskens, "Stone City, Iowa," Annals of Iowa 39 (1968), 261-74. On the claim of being the first art colony of its kind in the Midwest, see Robert Cron, "Iowa Artists Club Forms Art Colony in Deserted Stone City Mansion," Des Moines Register, 5/8/1932; and Adeline Taylor, "Picturesque Stone City Given New Life by Enthusiastic Art Colony," Cedar Rapids Gazette, 6/29/1932.

2. On the colony's housing situation, see Harlan Miller, "Stone City Colony Likely to Become Conspicuous Episode in American Art," Cedar Rapids Gazette, 7/31/1932.

3. Muyskens, "Stone City, Iowa." 


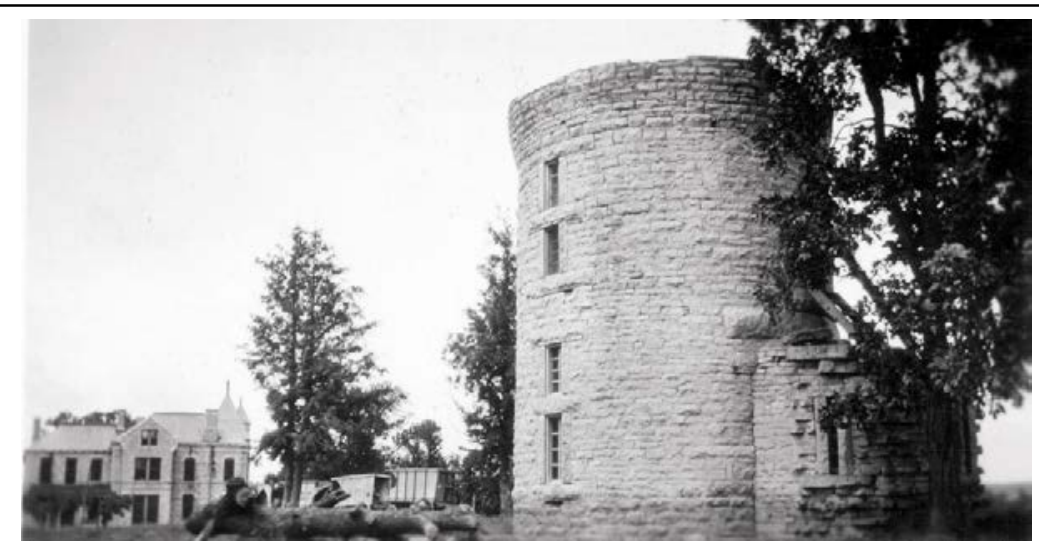

The stone tower at the Stone City Art Colony stands in the foreground, with the Green mansion in the background. Photo from State Historical Society of Iowa, Des Moines (SHSI-DM).

defined lines. The other ice wagon residents followed suit-in form, if not in style-adorning the interior and exterior of their wagons to suit their artistic whims (the interior of Wood's was sleek metallic silver). ${ }^{4}$

In 1932, when the Christian Science Monitor characterized the Stone City colony as a gay gypsy camp, the paper was not using the term in the same way it is used today - as a form of identification for individuals who embody same-sex desire. The term did, however, carry similar connotations. According to historian George Chauncey, by the 1920s and 1930s, in addition to its more common usage as a synonym of merry or fun, the word had long held allusions to "immoral pleasures," prostitution, and anything brightly colored, showy, or flamboyant - allusions that the Christian Science Monitor may have been making in its portrayal of the Stone City colony. Additionally, during those same decades, queer men - especially effeminate men who were often referred to as "fairies" - began to capitalize on the fluid character of gay, using it as a code word that allowed them to safely and covertly identify each other and friendly environments. Gay, however,

4. On the particulars of Wood's wagon, see R. Tripp Evans, Grant Wood: A Life (New York, 2010), 149-50. 
was not yet an identity, a term for a person, but simply a way of describing a particularly flamboyant, often effeminate style, which sometimes included male same-sex desire and sex. Gay as a fixed political or social identity would not come about until the 1940s, especially during and after World War II. ${ }^{5}$

Although the Christian Science Monitor's reporter may not have been aware of the use of the term among certain queer men (although, surely, some of the paper's readers were), the writer was potentially leveraging the protean properties of gay-its malleable and open-ended signification - to highlight the sexually non-normative possibilities of a group of artists camping out in the Iowa countryside. Or, at the very least, some of the paper's readers may have interpreted the headline as such. In 1932 an artists' colony in the middle of Iowa was a strange undertaking. Established in the midst of the economic challenges of the Great Depression and located far from major urban art centers, the Stone City Art Colony and School struck some observers as frivolous and even comical. For others, the venture was morally suspect, dangerously freewheeling, and sexually fraught. Like a band of gypsies, the artists were outsiders and were perceived as carrying with them many of the stereotypes of that particular vocation - sexual or otherwise. For a number of artists in attendance, however, queerness - non-normative forms of gender and sexuality - was more than just a stereotype that followed their artistic gifts. For some of them, including Grant Wood, it was an integral part of their lives.

Wood's queerness was then, and continues to be, a widely held open secret. During his lifetime, Wood's non-normative sexuality was generally acknowledged - albeit quietly and euphemistically - by reporters, colleagues, and friends. Born in 1891 on a farmstead just east of Anamosa, the so-called Glamour Boy of 1930s painters left the family farm when he was just ten, following

5. George Chauncey, Gay New York: Gender, Urban Culture, and the Making of the Gay Male World, 1890-1940 (New York, 1994), 16-23. On the importance of World War II for the development of gay identities and politics, see, for example, Alan Bérubé, Coming Out Under Fire: The History of Gay Men and Women in World War II (New York, 1990); John D'Emilio, Sexual Politics, Sexual Communities: The Making of a Homosexual Minority in the United States, 1940-1970 (Chicago, 1983); and Margot Canaday, The Straight State: Sexuality and Citizenship in TwentiethCentury America (Princeton, NJ, 2009). 
the death of his father, and moved with his mother and siblings to the outskirts of Cedar Rapids. ${ }^{6}$ Prevailing notions of art and art education sent Wood to the urban centers of Chicago, Minneapolis, Paris, and Munich, but he always returned to Cedar Rapids, to his mother, to his home, to the place where he found the greatest support and inspiration for his artwork.

Wood, art critic Thomas Craven noted in 1935, "lives in Cedar Rapids among people whom Sinclair Lewis would doubtless find rather odious. They are his friends, and the younger generation has acknowledged him to be the leader of a new school of art. He knows these people, knows what they are up to - how they think, feel and do business - he is one of them, and they are the material for his pictures." 7 Indeed, Wood posed his sister and his Cedar Rapids dentist as the dour-faced figures in American Gothic, and he received crucial financial and social backing from local businessmen. David Turner, for example, purchased many of Wood's paintings and gave the artist space above his mortuary's carriage house - known as Five Turner Alley - to use as a studio and home for himself, his mother, and his sister. Such local support came despite Wood's queerness, despite critic Arthur Millier's suggestion that, "for a farmer's son in Cedar Rapids, Ia in the 1910's to say that he wanted to paint pictures for his life work was as startling as for a girl to announce that she wanted to lead a life of shame." Millier even quoted Wood himself as saying, "'Painting was about on a level with tatting [lace] in the opinion of my fellow Iowans.'" 8

Yet Cedar Rapids - not New York or Paris - was where Wood found the most support for his work and where the nucleus of the Stone City Art Colony formed. And Stone City was where Wood's queerness - his otherness, his outsiderness - found its greatest expression. How did these two aspects of Wood's life, then - his queerness and his support in small-town Iowa - coexist, and why would the artist choose a tiny, out-of-the-way village in

6. “Could Be Good Farmer! Grant Wood Denies Reputation as Glamour Boy of Painters," Los Angeles Times, 2/19/1940.

7. Thomas Craven, "Grant Wood, of Iowa," Chicago Herald and Examiner, undated clipping, folder 1, "Clippings, 1932-1936," box 1, Grant Wood Papers, University of Iowa Archives, Iowa City.

8. Arthur Millier, “Bible Belt Booster,” Los Angeles Times, 4/7/1940. 
Iowa for the art colony he envisioned as the seed of a revitalizing national art movement? What was it about the small-town and rural spaces Wood inhabited that allowed this open secret to flourish? We can glean some answers to these questions by examining the rhetoric used in newspaper coverage of the Stone City colony and in personal correspondence dealing with Wood's career after Stone City. By tracing the allusions and euphemisms writers used to describe Wood and his activities, we can begin to understand the ways Wood's queerness and the queerness of others at Stone City was acknowledged by observers and made to fit in a rural landscape. Moreover, we can begin to see how Wood found relief from the pressures of marriage and other heterosexual dictates in a space like Stone City.

I use the term queer here and throughout this article to broadly indicate sexual non-normativity - the desires, people, identities, spaces, and ideas that circulate outside of the heterosexual norms of the dominant U.S. culture, what scholars of sexuality tend to term heteronormativity. Queer here is not synonymous with homosexual or gay, which are historically and culturally specific terms and concepts. Unlike other authors, I do not label Wood as gay or even homosexual, but as queer - as someone whose desire and sexuality operates largely outside of the heteronormative, which Lauren Berlant and Michael Warner consider "the institutions, structures of understanding, and practical orientations that make heterosexuality seem not only coherent - that is, organized as a sexuality - but also privileged." 9 Thus, my focus is not on who Wood may or may not have had sexual relations with or how Wood or others may have labeled his sexuality. Instead, I am interested in the way Wood was positioned, by himself and others, outside of heteronormative institutions and understandings and how, specifically, that positioning was articulated at the Stone City Art Colony and School.

The assertion of Wood's queerness is not in itself new. Art historians and other scholars have taken explicit notice of Wood's queerness for the past decade and a half and have sought to understand how the artist's non-normative sexuality was reflected

9. Lauren Berlant and Michael Warner, "Sex in Public," in Intimacy, ed. Lauren Berlant (Chicago, 2000), 312. 
in and through his artwork. In academic circles, at least, the open secret of Wood's queerness is now open acknowledgment. Most of these scholars, however, suggest that during his lifetime Wood felt the need to hide his queerness and perpetuate a sort of masculine normativity. ${ }^{10}$ By contrast, I suggest that, although Wood certainly sought to keep his private life private, in the 1930s his queerness was actually widely assumed and widely articulated through allusion and euphemism - in the press coverage surrounding Wood and the colony. Moreover, the rural landscape that surrounded the Stone City colony - not the major metropolises he visited as a young man - was the space where Wood's queerness was most at home and the space that offered him the greatest degree of freedom from heteronormative institutions like marriage and family. Indeed, as Wood left the pastoral space of Stone City in 1933 for the institutional landscape of the University of Iowa, a series of changes in the art world and in understandings of sexuality meant that the freedom Wood had experienced at Stone City was, by the 1940s, largely foreclosed, turning Wood's queerness into a liability.

\section{Stone City, Grant Wood, and "Lavender Language"}

When the Stone City Art Colony and School first began in the summer of 1932, Harlan Miller of the Des Moines Register traveled to the Wapsipinicon Valley and logged a lengthy report on the colony. He boldly hailed the experiment as one "not unlikely to become a most conspicuous episode in American art for 1932." The conspicuous nature of the colony, for Miller, grew from two seemingly glaring contradictions. The first was financial, the second spatial. How, Miller wondered, would such a venture fare during an economic depression, and was it financially wise to choose a location as remote as Stone City? Would it not, Miller

10. See, for example, John E. Seery, "Grant Wood's Political Gothic," Theory and Event 2 (1998), 1-35; Joni Kinsey, "Cultivating Iowa: An Introduction to Grant Wood," in Grant Wood's Studio: Birthplace of American Gothic, ed. Jane C. Milosch (New York, 2005), 10-30; Sue Taylor, "Grant Wood's Family Album," American Art 19 (Summer 2005), 48-67; idem, "Wood's American Logic," Art in America, January 2008, 86-91; R. Tripp Evans, "Departmental Gothic: Grant Wood at the U. of Iowa," Chronicle of Higher Education 57 (10/15/2010), B10-B11; idem, Grant Wood, 6 . 
implied, seem wiser to establish such a colony in a more urban, more traditionally art-friendly space, a space where the artists would be less "conspicuous"? Miller resolved these contradictions by proclaiming art to be the eternal "business of the soul," profitable wherever it might appear. "As Americans know," he wrote, "business comes and goes. As Americans often forget, no matter how often reminded, only art is eternal. It goes on forever, cropping out in astonishing places, the business of the soul thriving even in lean times. ... Now art has pitched its easel on this rugged Iowa hillcrest, ... . snuggling down among the cows and plows and rural populace as if it belongs there." 11 Art and, by extension, artists, Miller suggested, were not natural elements of the Iowa countryside.

One reason art and the rural landscape seemed so disconnected for Miller was that in the decades prior to the 1930s, art centers and the subject of art itself were city-based. In the years just after World War I, modern artists had, according to art historian Wanda Corn, "focused on industrialized America, replacing the iconography of Niagara Falls and the Rocky Mountains with that of skyscrapers, billboards, brand-name products, factories, and plumbing fixtures." 12 Before the arrival of Regionalism, modern art, indeed modern America, was the city. Wood and other Regionalists, such as Thomas Hart Benton and John Steuart Curry, turned away from this urban focus, which Wood claimed was still far too indebted to the European scene, as they sought to stake out the landscape of a truly and purely American art. Wood and the Regionalists, however, were not simply returning to the romantic landscapes of the mid-nineteenth century, which celebrated the wild and sublime expanses of the American continent as the nation marched steadily westward. Instead, Wood, for example, openly rejected the European-style Impressionism of his earlier work, turning rather to a hard-edged, often satiric style that was brought to bear on scenes of everyday life in Iowa and the Midwest more generally, a section of the country Wood envisioned as the central locus of a new Regionalist art move-

11. Miller, "Stone City."

12. Wanda Corn, The Great American Thing: Modern Art and National Identity, 1915-1935 (Berkeley, CA, 1999), xv. 
ment. ${ }^{13}$ In disconnecting American art from urban and often European centers, however, Wood and the other Regionalists faced an uphill battle.

As long as landscapes have been considered an appropriate artistic subject, artists have ventured into the countryside to find vistas suitable for their work. Art education, galleries, and artists themselves, however, have more often than not been intimately and inextricably associated with the urban. Moreover, for a halfcentury or more before Wood and his colleagues opened the Stone City colony, art and artists were often connected to what was perceived to be a particularly urban vice. During the nineteenth and twentieth centuries artists became inextricably connected with the bohemian and the queer. Indeed, during this period, art and queerness seemed paired as naturally as farmyards and the Iowa countryside. Art historian Christopher Reed, for example, argues that artists and various medical categories of homosexuality had been intimately entwined and even mutually constitutive since at least the nineteenth century. The sensational (and sensationalized) 1895 trials of Oscar Wilde for gross indecency solidified that connection in the eyes of the public in both England and the United States. Even though Wilde was not a visual artist himself, his trial unequivocally linked avant-garde art and the developing definitions of same-sex desire, as his own work was paraded before the court and used as evidence to convict and label him as a sodomite. After the term homosexual began to appear in the same decade, the artist and the homosexual were often viewed as one and the same. ${ }^{14}$

Thus, when Harlan Miller and other journalists visited the Stone City Art Colony, they were faced with a group of individuals tinged with queerness and set down in a post-industrial rural landscape far outside their "natural" urban environment. But rather than condemn, ostracize, or lament the presence of queer artists like Wood, visitors and neighbors generally greeted the colony with lighthearted suspicion and knowing humor - with what historian John Howard calls the "heterosexual will to not-know." 15

13. See, for example, Kinsey, "Cultivating Iowa," 24.

14. Christopher Reed, Art and Homosexuality: A History of Ideas (New York, 2011), 94.

15. John Howard, Men Like That: A Southern Queer History (Chicago, 1999), xvi. 
This is the ability to see queerness and to tacitly acknowledge it, to implicitly tolerate it but explicitly deny its presence. It is the knowing wink, the surreptitious nod, and the cryptic gesture, and is most often spoken through allusion, metaphor, and euphemism. For Howard, this ability to look the other way, to feign ignorance about a queer individual or group, was especially powerful in rural and small-town spaces because homosexuality and homosexuals could always be located somewhere else-notably, in the city - and the "discovery" of queerness could always be figured as something new, something previously unknown. That was precisely what allowed the queerness of artists like Wood, and of the Stone City colony in general, to be so snugly incorporated among the hills of the Wapsipinicon by journalists and commentators like Miller.

In many ways, much of Miller's piece is itself a study in feigned ignorance, in the "heterosexual will to not-know." After waxing eloquent about art as the business of the soul, for example, Miller took care to reaffirm his own credentials as a man's man (just not that kind) by parenthetically claiming that the temptation to get all touchy-feely was just too much, given the surroundings and the company. "No ignorant layman like me," Miller wrote, taking care to place himself outside of implicitly queer artistic circles, "could write about an art colony without indulging in a little flight of lavender lingo." 16 By the 1930s, lavender was a color that connoted both effeminacy and homosexuality, and Miller's invocation here was likely meant to signal the perceived queerness - the otherness - of art and artists. ${ }^{17}$ But Miller reassured his readers that that particular linguistic temptation was only a passing fancy for himself and for colony residents as well. The artists in Stone City - tinged with lavender as they may have beenwere really good, hard-working folks who got along well with their new neighbors. "The natives are extremely friendly and hospitable to the artists," Miller wrote. "In the [nineteenth-century] boom days an art colony might have been regarded as freakish; today it strikes the populace as somewhat heroic." 18 Artists, odd

16. Miller, "Stone City."

17. Jonathon Green, Cassell's Dictionary of Slang (London, 2003), 718.

18. Miller, "Stone City." 
as they were, were bringing the community back to life-at least for a few months out of the year. Even if the colony was not to last (and it did not), at least it was momentarily a profitable venture for some of the local residents who supplied the colony with food and other necessary goods. ${ }^{19}$

Moreover, when it came to the question of sex, Miller guaranteed that there was "No Call for Chaperones," as the sleeping quarters of male and female students were separate and the whole encampment was far too busy and too familial in nature for any possible impropriety. Notably, Miller pointed out that "several sets of husbands and wives are enrolled, too; but their chaperonage is hardly needed. There is a man-to-man, brother and sister attitude between the sexes. And everyone is working too hard painting to romance a great deal." 20 Despite his assurances, however, Miller's piece, at times, seems a bit too anxious to make his point. Regarding the ice wagons where Wood and a handful of other men lived, for example, Miller wrote, "These ice wagons hold just one cot each, a tight squeeze, with mosquito netting to rebuff mosquitoes and wandering visitors." 21 Either Miller did not actually visit the wagons (or at least not all of them) or he was feigning ignorance to construct a particular narrative to erase the possibility of sex, and of queer sex in particular.

Wood's own ice wagon, for example, held sleeping space for - and indeed housed - more than one person. As Wood's most recent biographer, art historian R. Tripp Evans, found, "John Bloom, the colony's groundskeeper and later a celebrated artist in his own right, shared Wood's wagon for much of that first summer." 22 Additionally, in one of her many columns for the Cedar Rapids Gazette, Adeline Taylor noted that in the colony's second season Wood again shared his wagon with a fellow artist,

19. As it turns out, the colony was far better at art than accounting. During both summers of the colony it purchased supplies and goods from various local merchants, much of it on credit that was not paid off until 1934. See, for example, Grant Wood to John C. Reid, September 1934, folder 1, box 1, John C. Reid Papers, Special Collections, University of Iowa Libraries, Iowa City.

20. Miller, "Stone City."

21. Ibid.

22. Evans, Grant Wood, 151-52. 


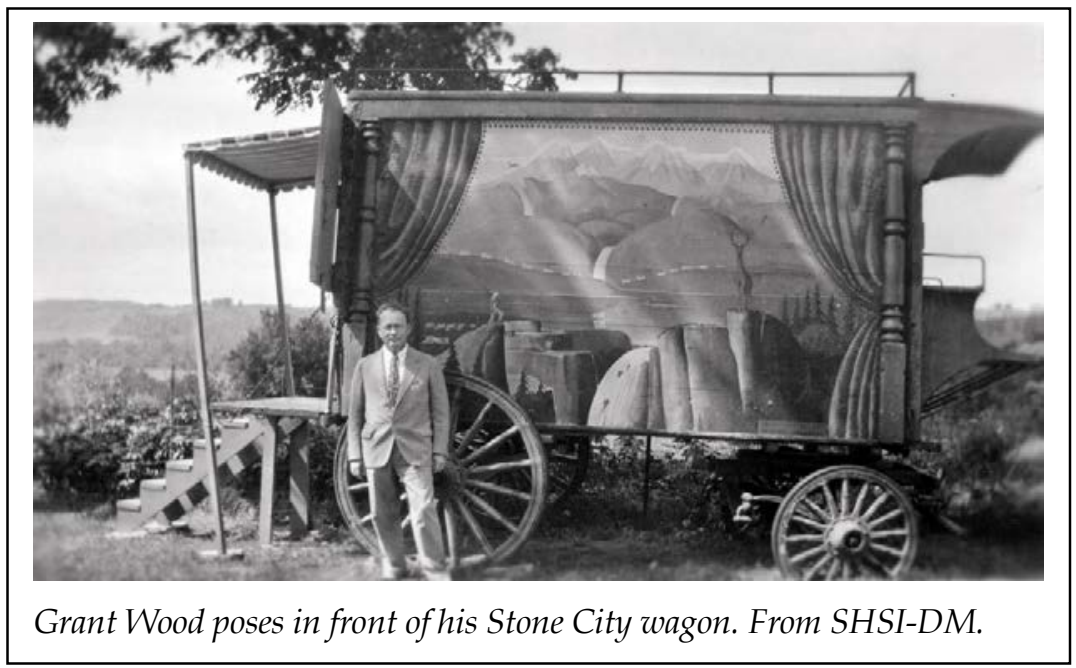

this time with "Charles Keeler of California . . . famous for his etchings." 23 While these rooming couples may have had perfectly platonic relationships, the point is that Miller either never visited the wagon of the most famous artist at the colony or chose to ignore and instead speak euphemistically about the possibility of queer liaisons at Stone City. Mosquito netting, after all, might work fine for bloodthirsty insects, but it would likely be a poor deterrent for "wandering visitors" in the form of other colonists - of either sex.

Wood actually gets little coverage in Miller's piece, as the journalist's focus was more generally on the colony as a whole. Still, the article opened by describing the colony's most highprofile resident as a visual paradox in rural masculinity: "A muscular, ruddy, broad browed man in overalls ... on an Iowa hilltop fingering a magazine newly arrived from London." ${ }^{24}$ Masculine characterizations were not absent in journalists' depictions of Wood, as similar articles described the artist as "a sturdy, foursquare son of the Middle West." 25 But such descriptions were in the minority, and when they did appear they often echoed Miller

23. Adeline Taylor, "Sickle and Sheaf, Recreation Center for Art Colony, Is Christened at Stone City," Cedar Rapids Gazette, 7/2/1933.

24. Miller, "Stone City."

25. Arthur Millier, “Bible Belt Booster," Los Angeles Times, 4/7/1940. 
and hinted at Wood's lack of masculinity even as they celebrated it. Following Miller's example, other journalists articulated Wood's queerness through small comments on his character, appearance, or mannerisms, suggesting that there was something less than masculine about him. Few real Iowa farmers, for example, were likely reading European magazines. In this way, journalists undermined Wood's masculinity by portraying him as effeminate, soft, and uninterested in women.

In December 1934, for example, a year-and-a-half after the colony's second summer, Time magazine ran a piece proclaiming the arrival of Regionalism on the national art scene. "In U.S. sales of contemporary paintings," according to the story, "observers noted a significant difference. This year the French schools seem to be slipping in popular favor while a U.S. school, bent on portraying the U.S. scene, is coming to the fore." As leaders of this new movement, Wood, Benton, and Curry each received an extensive write-up in the piece. In detailing the lives of each of these men, however, Time positioned Wood's queerness in rather stark relief from Benton and Curry's masculinity. Benton, for example, was hailed by Time as "the most virile of U.S. painters of the U.S. Scene" - "a short wiry man with an unruly crop of black hair, [who] lives with his beauteous Italian wife and one small son in a picture-cluttered downtown Manhattan flat." As if Benton's heterosexual prowess was not enough to prove his masculinity, the writers at Time also noted his disavowal of effete and ultimately effeminate styles of French Impressionism. "At 17," the authors tell us, "artist Benton gave up a job as surveyor's assistant in the lead and zinc district outside Joplin to do newspaper cartoons. A bad art student in Chicago, he went on to Paris, where he speedily absorbed and copied all the latest French fads. Six Wartime months in the U.S. Navy knocked French Impressionism out of him." A surveyor in the mining district, a sailor, and a bad art student who rejected foreign forms of art, Benton was about as manly an artist as an artist could be. By comparison, Curry's gender presentation received far less attention, but Time did note that this "simple and dramatic" painter, despite now being "applecheeked, fat, and bald," was once "a potent footballer." 26

26. “U.S. Scene,” Time, 12/24/1934, 26-31. 
Grant Wood was no footballer. He was a soldier during World War I, but Time neglected to mention that, perhaps because he never saw Europe and spent most of his time in the army recovering from appendicitis and sketching portraits of fellow soldiers - “doughboys 25 cents, officers \$1." 27 The Baltimore Sun, in its 1935 write-up on Wood, saw the artist's "queer experience" in the army - his illness, artistic ventures, and lack of deploymentas a launching pad for his artistic career. "From a shy boy, wistful to be liked, he became popular," art critic Frederic Newlin Price wrote, "for by some strange reaction his drawings won folk to him. ... The bashful boy, who had wept when asked to read in school, had found his entrée into life." Time magazine echoed Price's characterization of Wood as shy and bashful, intimating a kind of softness or even weakness, when it labeled the "chubby, soft-spoken Wood" as Regionalism's "chief philosopher and greatest teacher." In contrast to its emphasis on Benton's virility and Curry's gridiron achievements, the magazine noted that "shy Bachelor Wood, 42, hates to leave his native Iowa where his fellow-citizens have been buying his pictures and singing his praise almost since he began painting." 28

Wood may have found his calling as an artist while in the army, but most renditions of his life story, including his own wellrehearsed version, held that it was his interwar trips to Europe that eventually led him to his mature painting style and fame as a Regionalist artist. His first trips to Europe, however, did nothing to challenge the stereotypes of bohemian artists. "He raised a pink beard," the Des Moines Register wrote after Wood's death, "dressed in traditional Bohemian fashion, and turned out many Europe-influenced paintings, most of them forgotten." 29 As Evans shows, bohemian was one of those words - similar to gaythat held seemingly boundless allusions to improper sexuality,

27. This story was told in detail by the Baltimore Sun in 1935, but passed over quickly by R. Tripp Evans. Following Wood's sister, Nan Wood Graham, Evans suggests that Wood was in the hospital with appendicitis and not, as the Sun tells it, because of "an anthrax plague through an epidemic of the 'flu.' " I've chosen to follow Evans here. Frederic Newlin Price, "The Making of an Artist: The Americanism of Grant Wood," Baltimore Sun, 1/20/1935; Evans, Grant Wood, 38.

28. Price, "The Making of an Artist"; "U.S. Scene."

29. "Final Tributes to Grant Wood," Des Moines Register, 2/15/1942. 
to queerness. Moreover, he notes, by the 1920 s beards "had evolved from a sign of manliness to a suspect, and nearly opposite, meaning." 30 And then of course there was the odd color of the thing-identified as pink, a color that, along with lavender, had long been associated with effeminacy and homosexuality. ${ }^{31}$

Shortly after returning to Cedar Rapids, Wood was convinced to shave off his pink beard (which, of course, was really red). In the narrative of Wood's artistic discovery of his midwestern roots, this act came to symbolize his rejection of European schools of painting in favor of the mature, hard-edged style and local subjects that made him famous. ${ }^{32}$ Although Wood dropped the bohemian beard and eschewed Impressionist styles, the earlier characterizations of his queerness stuck.

Echoing both Time's emphasis on Wood's "bachelor" status and the Register's use of the color pink, writer MacKinlay Kantor painted a decidedly queer image of Wood after visiting the artist's Cedar Rapids studio at Five Turner Alley.

Grant Wood is a bachelor, and lives with a quiet, sweet faced woman who is his mother. ... He has a disappearing cupboard, disappearing dining table and disappearing bed. Everything but the bathtub is apt to disappear at a moment's notice.... Pink of face and plump of figure, Iowa's most famous artist calls forth the mental adjective "cherubic," "seraphic" and all the rest. Perhaps he was most nearly in character one night when he appeared at a costume party dressed as an angel-wings, pink flannel nightie, pink toes and even a halo supported by a stick thrusting up from his back. ${ }^{33}$

Here again we see Wood in pink-specifically a "pink flannel nightie" - but this time as an angel rather than a bohemian. And not a masculine warrior like the angel St. Michael, but a sweet, chubby, feminized, asexual cherub of classic paintings or Valentine's Day greeting cards. Additionally, Wood's bachelor status was not only named but reinforced by his mother, sitting quietly in the corner almost as if a piece of furniture. While it was not

30. Evans, Grant Wood, 46-47.

31. Wayne Dynes, Homolexis: A Historical and Cultural Lexicon of Homosexuality (New York, 1985), 33; H. Max, Gay(s)Language: A Dic(k)tionary of Gay Slang (Austin, TX, 1988).

32. Evans, Grant Wood, 47.

33. MacKinlay Kantor, “K's Column,” Des Moines Tribune-Capital, 12/20/1930. 
unusual, in this era before Social Security, for elderly parentsespecially widows - to live with their children, Kantor's emphasis on Wood's bachelorhood makes her inclusion seem meaningful. Moreover, Kantor combined these descriptions of Wood with the unique, disappearing elements of the studio's décor. While these elements were important and inventive space-saving strategies Wood used in his tiny studio apartment, Kantor's highlighting of the strategies might also be meant to suggest-along with Wood's bachelor status, his pink angel costume, and the stoic presence of his mother - that Wood's life contained secretive elements meant to be concealed, though not repressed or disavowed. ${ }^{34}$

Wood's cupboard, dining table, and bed-like his queerness - may have been concealed, but Kantor knew they were there and shared this only partially hidden fact with his readers. Indeed, the secret of Wood's queerness, up through the 1930s at least, was really no secret at all-nor did it seem to pose much of a threat, as Wood often adopted the language of feigned ignorance to describe himself. For those who could read through the thinly veiled allusions used to characterize Wood and artists like him, the "primrose path" of queer artists was fully visible in and through the "lavender language" used to describe them. ${ }^{35}$ More to the point, this lavender language - by naming queerness implicitly but explicitly disavowing it - worked to create space for queer individuals in the small towns and rural spaces where they were generally thought not to exist. That is how Wood was able to make his home and find his greatest support in Cedar Rapids. That was also how Harlan Miller was so easily able to fit a misfit group of artists so snugly in amid the pastoral landscape of Stone City. And that is one way the pastoral setting of Stone City, for the bachelor Wood at least, served as a queer respite from the more heteronormative demands on him back in Cedar Rapids.

34. For a different reading of this passage, see Evans, Grant Wood, 60.

35. This reference to Wood traveling a primrose path comes from a 1935 North American Review article examining Wood's work: "By his own confession, Wood has been too much entranced by the prim patterns on old china. In his landscape, sometimes, he prettifies the Iowa fields, diluting their abundant fertility to tea-cup graciousness. ... Wood, I think, will fight out of this primrose path." Ruth Pickering, "Grant Wood, Painter in Overalls," North American Review 20 (September 1935), 271-77. 


\section{Otherness and Pastoral Possibilities at Stone City}

On its face, a run-down, nearly depopulated, nineteenth-century industrial boom town hardly strikes one as a promising and powerful pastoral setting. For two summers, however, it was the space where Grant Wood came closest to realizing his vision of a Regionalist art movement and where he was most removed from the pressures of heteronormative society he likely felt back in Cedar Rapids. In Stone City, Wood was able to look past the largely abandoned limestone quarries and uninhabited buildings to envision the pastoral possibilities of the tiny village. According to art historian James Dennis, Wood's vision of Stone City - or his painterly vision of it, at least-embodied much of what historian Leo Marx identified as the conflicted and contradictory nature of American pastoralism. For Marx, American pastoralism was symbolized by, among other things, the Jeffersonian yeoman farmer as he existed in a "middle landscape" between wilderness and an industrialized society. ${ }^{36}$

Wood's rendition of the colony's home, simply titled Stone City, captures the myth of the middle landscape. The farmscapes of the town and surrounding area dominate the few markers of industrialism Wood provided. The large limestone quarry, for instance, which Wood placed prominently near the center of the piece, appears as an almost natural feature of the landscape, were it not for the terraced steps leading from the river to a well-hidden crane, its uppermost spires barely emerging above a dense tree line. To the far right of the frame Wood playfully added a water tower, although he omitted one of the most powerful symbols of American industrialism - the railroad - which the tower would have served. Additionally, despite the absence of modern vehicles (the winding road that traces across the painting is traversed by just a single horse and its rider), Wood placed two modern billboards at the roadside. Accenting the already sensuous curves of Wood's landscape, one of these billboards was charged - for the select viewers who could read such coded symbols - with erotic

36. James M. Dennis, Grant Wood: A Study in American Art and Culture (Columbia, MO, 1986), esp. chap. 11, "Cultural Tradition: The Machine in the Garden," 212-15; Leo Marx, The Machine in the Garden: Technology and the Pastoral Ideal in America (New York, 1964). 


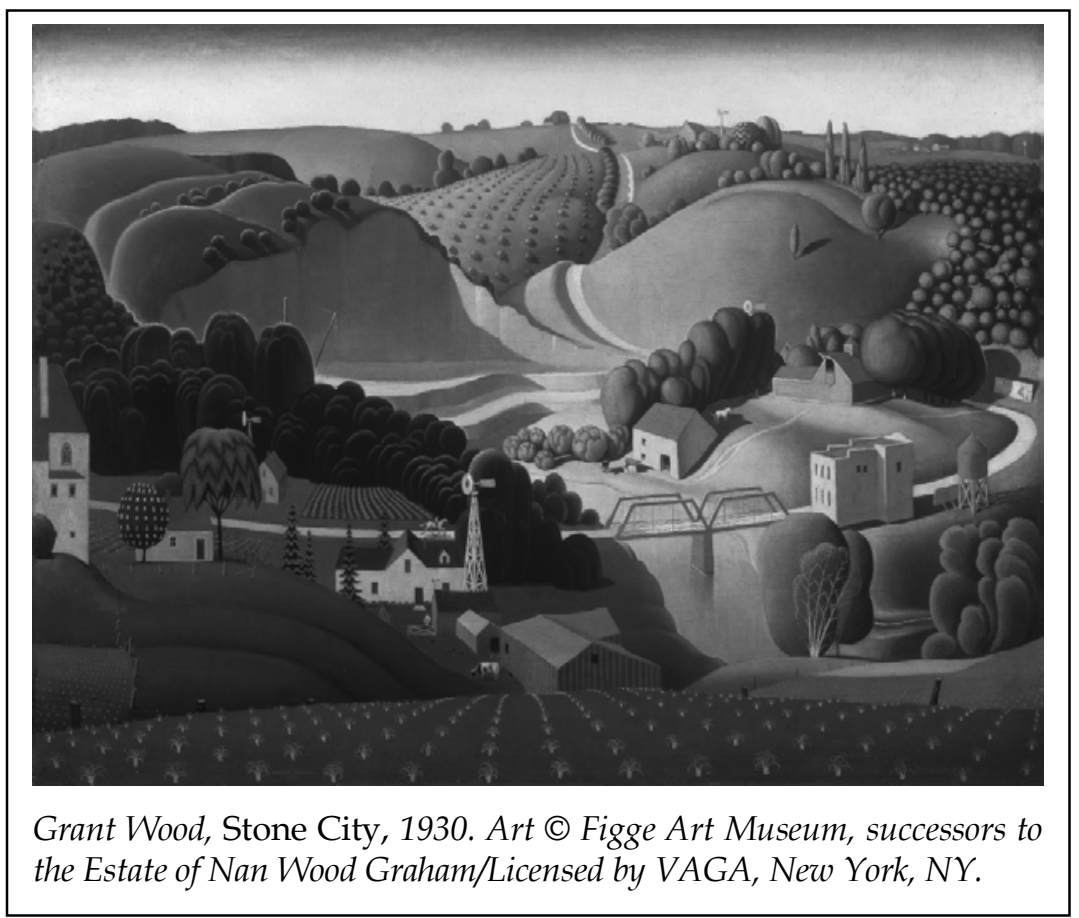

meaning: the billboard facing the painting's audience displays the faint image of a man in a red tie-a 1930s urban sartorial code for male homosexuality - smoking a cigarette, with copy that suggestively reads: "They Satisfy." 37

In Wood's vision, then, Stone City was a distinctly pastoral place in the American sense: a middle landscape where agrarian mythology and modern industrialism were mixed, and wherefor Wood, at least - the latter could be easily subdued and playfully twisted, sometimes in queer ways. In Wood's rendering of Stone City, in other words, the artist could feign a certain degree

37. The sensual-even sexual-curves of Wood's landscapes have been noted by several scholars. See, for example, Wanda Corn, Grant Wood: The Regionalist Vision (New Haven, 1983), 90. R. Tripp Evans, however, is the only scholar to suggest that-given Wood's queerness - we should read these curves as evoking a male-male, same-sex eroticism. For a specific discussion of Stone City in this context, see Evans, Grant Wood, 131-35. On the red necktie as a symbol of urban male homosexuality, see Chauncey, Gay New York, 52; and Evans, Grant Wood, 136. 
of ignorance regarding the incursions of industrial capitalism and its deleterious effects on modern life.

This feigned ignorance- or at least the appearance and portrayal of it-extended to the Stone City colony as well. Much like Miller's description of art as the "business of the soul," the Cedar Rapids Gazette, which devoted significant ink and space to Wood's venture, saw the Stone City colony as combating the effects of the depression by, for the most part, ignoring it. In its announcement of the colony's opening in late June 1932, for example, the Gazette proclaimed,

From the jovial appearance of the faculty one would surmise that here is at least one group in Iowa who is not taking the depression too seriously. At any rate, they are not depressed. But then artists have never been known to be worried about stocks and bonds. Their philosophy of art as a motivating power of life and happiness has stood them in good stead since they have put over a big proposition in times which would have baffled many an able business man. ${ }^{38}$

Cedar Rapids Gazette columnist Adeline Taylor, who penned several lengthy, glowing pieces on the colony and its participants, also claimed that there was "No Talk of Depression" among the colonists, as art and the pastoral scenery served as a reinvigorating diversion. "There is the same fresh spontaneity among the students as there is about the gorgeous scenery in those hills," she wrote. "No talk of deflated incomes - money is neither thought nor talked of. There is something else to think of than the dollar sign out there among high reaching bluffs and timbered hills." 39 For journalists like Taylor, the pastoral setting of the Stone City colony created a space somehow separate and distinct from the surrounding towns, villages, and farms suffering under the weight of the Great Depression. For these writers, the presence of the artists and their colony created a space apart, a haven and a respite from the surrounding world and its concerns-economic or otherwise.

38. "Stone City Art Colony Will Be Opened Today: Its Enrollment Has Exceeded All Expectations," Cedar Rapids Gazette, 6/26/1932.

39. Taylor, "Picturesque Stone City Given New Life." 


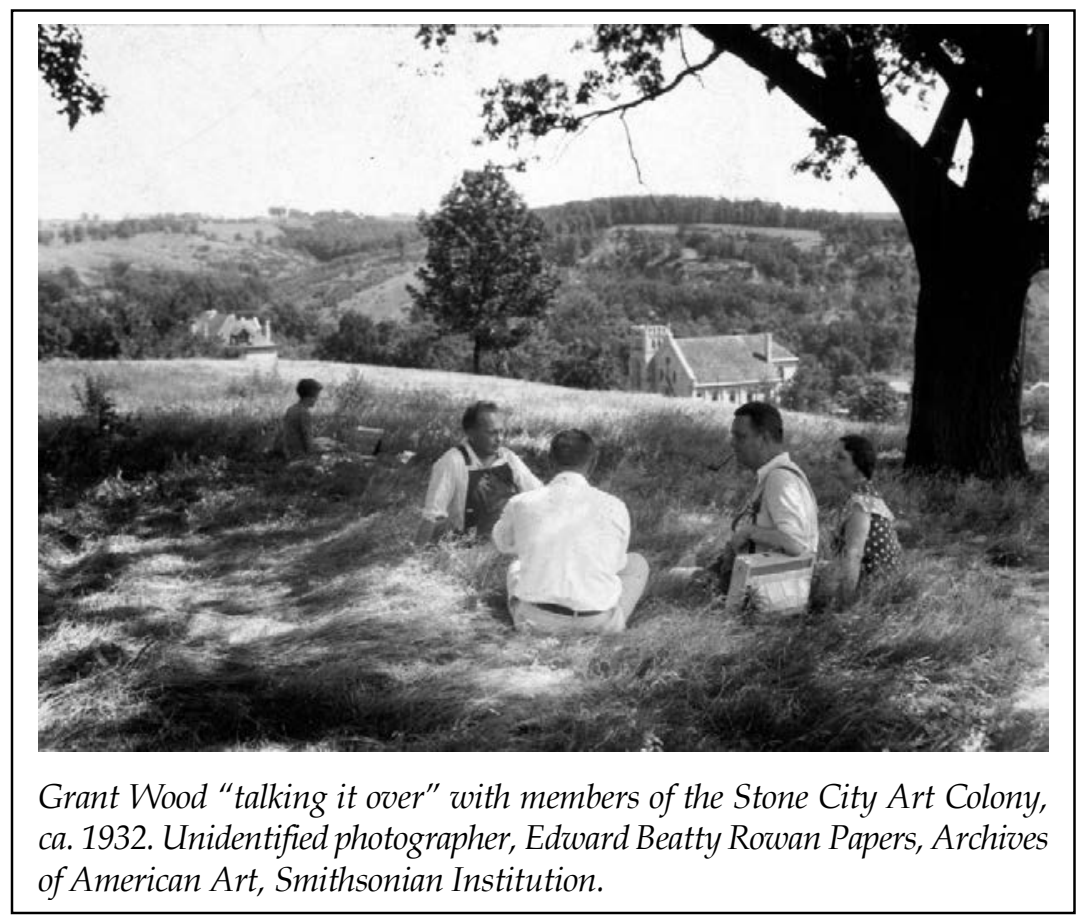

The pastoral scene of the Stone City colony was also, in many ways, portrayed as a place out of time. Much of the press coverage envisioned the colony as the rebirth of Stone City. One headline from columnist Taylor, for example, proclaimed, "Stone City Given New Life by Enthusiastic Art Colony"; a similar article was capped with the opening, "City of the Dead Comes to Life Again." 40 Drawing on themes of rebirth, these articles evoked what the scholar Raymond Williams, in his famous text on the pastoral in literature and social history, called the Golden Age. ${ }^{41}$ This, in the pastoral tradition of English literature, was an imagined historical moment free of strife and void of conflict. In 1932, for the Cedar Rapids Gazette, the nineteenth-century Golden Age of Stone City was almost positively Edenic - that is, until the arrival of a serpent in the form of cheaper Portland cement:

40. Ibid.; Miller "Stone City."

41. Raymond Williams, The Country and the City (New York, 1973), esp. chaps. 1-4. 
And so it came to pass that from 1850 until 1894 money and dreams worked in perfect accord, and the sun shone brightly on a community which numbered some seven hundred inhabitants. But a great storm broke in 1893, in the way of the introduction of Portland cement, and it violently shook the stone foundation on which Stone City rested. From that day to this, it has been almost a deserted village, the workmen long since gone and the bleating of sheep almost the only sound to be heard. ${ }^{42}$

The vast majority of earlier Stone City residents - those who actually labored in the quarries - likely never saw "money and dreams" work in "perfect accord." Workers at one quarry, in fact, went out on strike in 1890 , demanding $\$ 1.70$ per day and putting up "a stubborn fight." ${ }^{43}$ But within the pastoral tradition, it is the function of the Golden Age to erase, to ignore, or at least to feign ignorance of such conflict.

Crucially, some poets and artists see it as their job to keep the mythical Golden Age alive. Des Moines Register reporter Robert Cron understood this role of the artist. "There is vivid history written in the steep hillsides and stone walls of Stone City," he wrote, "history that was all but forgotten, but which the artists' colony hopes to revive. . . . Now Iowa artists hope to glorify the section, to paint the pathos and glory that was once Stone City." 44 This was the essence of what Wood saw as the primary goal of Regionalism and the Stone City colony: to work towards a "national expression," a distinctively American form of art, and not one that functioned as "a mere reflection of [European] cultural expression." 45 To accomplish this, Wood hoped to cultivate a series of regional art centers that would engage directly with the

42. Grace Boston, "Stone City Is Ideal Setting for Colony and Art School Planned by Cedar Rapids Artists," Cedar Rapids Gazette, 5/15/1932.

43. "Miscellaneous Labor News: Quarrymen at Anamosa, Ia., Demand an Increase in Wages," Chicago Daily Tribune, 5/2/1890.

44. Cron, "Iowa Artists Club Forms Art Colony."

45. These statements appeared in the colony's mission statement, titled "Aim of the Colony," which was printed in a pamphlet used to attract artists to Stone City. Stone City Colony and Art School, 1933, folder 1, box 6, Grant Wood Papers (also accessible at www.aaa.si.edu/collections/grant-wood-collection-9365). As numerous scholars have pointed out, the irony of this central goal of Regionalism was, for Wood at least, still heavily indebted to European techniques and styles. The rhetoric of Regionalism erased and ignored that indebtedness. See especially Brandy M. Roberts, "The European Roots of Regionalism: Grant Wood's 
local landscape and immediate environment as each center gradually developed its own regional style. Stone City, then, was intended to be just the beginning and the model for other regional centers. As the colony's mission statement posited, "An American art will arrive through the fusion of various regional expressions based on a thorough analysis of what is significant to these regions. Stone City Colony has this for its objective." 46

Not only journalists, but also art school educators and critics as well, shared this enthusiastic vision. In the weeks before the colony's first season, for example, the Cedar Rapids Gazette quoted the Chicago lecturer and critic Dudley Crafts Watson as proclaiming, "The great age of machinery has done its worst and its best for us. We are emancipated, the whole race has freedom, and with that freedom comes despair, depression, and total indolence unless we develop our talent. The colony should grow in two or three years into a great, splendid, flourishing thing, more important than Chautauqua has been in the east, more important than most summer colleges." 47 Stone City, then - "The Quarry Town That Came to Life Again as an Art Center" - was to be the model for a nationwide art movement, an American Renaissance that would help alleviate the effects of European dominance in art and begin to heal the wounds of the Great Depression by breathing new life into a mythical American landscape gasping for breath. ${ }^{48}$

As journalists' emphasis on Stone City's Golden Age and its artistic resuscitation illustrates, this mythical American landscape was one that was not only spatially but also temporally outside the normal workaday world. Crucially, it was the otherness of the space of Stone City and its art colony that offered the potential of safe harbor to a variety of outsiders: artists, queer folks, and, according to journalists, even ghosts, the long-dead inhabitants of the Golden Age. Although a handful of residents remained in

Stylistic Synthesis," Grant Wood: An American Master Revealed (Davenport and San Francisco, 1995).

46. "Aim of the Colony."

47. “Art Institute Lecturer Favorably Impressed by Stone City Art Project," Cedar Rapids Gazette, 6/5/1932.

48. "The Quarry Town That Came to Life Again as an Art Center," St. Louis PostDispatch, 8/13/1933. 
Stone City in 1932, the village was often portrayed as "deserted" and devoid of human life. ${ }^{49}$ Harkening back to the ancient pastoral poetry of Virgil and others, for example, Robert Cron suggested that the "verdant" hills of Stone City were "cropped short by grazing sheep, the only animal hardy enough to munch a living from them"; apparently unshepherded, the sheep commingled not only with the colonists, but with the undead, as the colony's artists "started ghosts walking in Stone City." 50

Wood's first biographer, the Iowa journalist Darrell Garwood, evoked the spectral nature of Stone City when he described what was so unique about the place that Wood chose for his colony. In Stone City, according to Garwood, the land itself was uniquely separate and distinct from the landscape that surrounded it. That separateness echoed pastoral notions of rest and respite, but it also signaled the possibility of a fresh perspective, a different sort of vision, a different way of living.

For some reason the limestone that lies in tilted beds under Iowa's soil came to the surface around Stone City. It pushed up the ground in a series of hills and ridges. The Wapsipinicon has cut a deep valley through them, and it ducks under trees that grow out of the steep banks and almost meet overhead. There is relief in this stony section, after so much rolling land all around. It is a place for ghosts to hide out, for small boys to explore caves under limestone ledges and for artists to find how feverish the usually complacent lines of the Iowa landscape can become. ${ }^{51}$

Stone City, for Garwood, was a place of "relief," both in the topographical sense and in the ability of ghosts, young boys, and artists to get away, to remove themselves from unwanted and undesirable situations. Whether those situations were death, overbearing parents, or heteronormative demands, Stone City, for Garwood, was both a space and a time apart from the surrounding Iowa landscape and, as such, was a space perfect for Wood's art colony.

49. On the characterization of Stone City as "deserted," see Boston, "Stone City Is Ideal Setting"; Cron, "Iowa Artists Club Forms Art Colony"; and "Stone City Art Colony Opens with 100 Students Enrolled," Cedar Rapids Gazette, 6/27/1933.

50. Cron, "Iowa Artists Club Forms Art Colony." On the theme of ghosts and rebirth, see also Adeline Taylor, "Columbia Hall, Hotel and Theater Building at Stone City May Be Revived by Art Colony," Cedar Rapids Gazette, 7/3/1932.

51. Darrell Garwood, Artist in Iowa: A Life of Grant Wood (New York, 1944), 143. 
The Stone City Art Colony and School was not Wood's first attempt to create a distinct and separate artistic space in his home state. Back in Cedar Rapids in the mid-1920s, Wood and a group of artists in the city had wanted to create an urban art colony centered on Wood's studio at Five Turner Alley. The colony never materialized, partly because of the excessive costs associated with converting the nearby buildings into studios but also because residents were anxious about the queer possibilities of a "Greenwich Village of the Corn Belt" in the heart of Cedar Rapids. ${ }^{52}$ But outside of the city, in the pastoral landscape of Stone City, the artists were able to find their place as outsiders. There-on the outskirts of the village, tucked into the hillsides - the artists of the Stone City Art Colony and School could find a place for themselves apart from the economic realities of the depression and, for some, outside of dominant and heteronormative institutions.

The otherness of the Stone City colony was expressed in many ways, but most notably in the journalistic obsession with the ice wagon homes of some of the colonists and the living arrangements and private lives of the artists more generally. Taylor's early coverage of the colony, for example, likely served as the model for the Christian Science Monitor headline, as she was the first to describe the wagons as "painted in gay colors and dressed up in grand designs like a gypsy caravan." In subsequent articles on the colony, she wrote about the "ice-wagon vagabonds" and devoted an entire column to her visit to one of the more "interesting" abodes in the "Exclusive Wagon Row": Reggie Correthers's "Bohemian carnival home." 53 Edward Rowan, a fellow colonist who ran the Little Gallery in Cedar Rapids and promoted Wood's work, also picked up on this characterization of the "romantic" wagon encampment. "A touch of the gypsy is there," he observed, "a note of old Bohemia and the bizarre of nomadic life." 54 This framing of the ice wagons as gypsy-like, bohemian, carnivalesque,

52. Evans, Grant Wood, 58.

53. Taylor, "Picturesque Stone City Given New Life"; idem, "Columbia Hall"; idem, "We Go Calling in Exclusive Ice Wagon Row at Stone City and Hear Tales from Reggie," Cedar Rapids Gazette, 7/17/1932.

54. Edward B. Rowan, “Old Ice Wagons, From Which Girl Once Helped Herself, Aid in Realization of Artist Career," Cedar Rapids Gazette, 7/3/1932. 


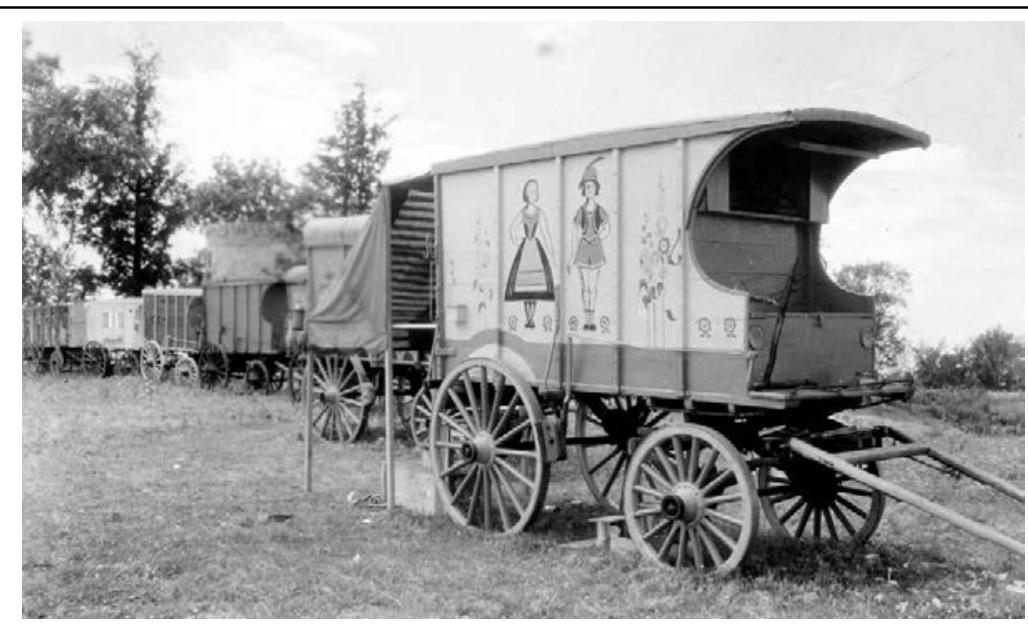

Wagons at the artist camp at the Stone City Art Colony. Unidentified photographer, Grant Wood Collection, Archives of American Art, Smithsonian Institution.

and the like worked to emphasize the difference - the otherness - of the artists and their colony. So too, did journalists' concern with the appearance and dress of the artists themselves.

When Taylor spent the afternoon with Reggie Correthers, for example, she noted his artist's smock before sharing the fantastic tales with which Correthers regaled her. "Attired in his bright blue smock," she wrote, "'Reggie' is the perfect host, pouring tea and tales for his guests - tales of designing opera sets for Melba in Australia, making stage costumes for the London court designers, fixing up feathered things for the beauteous Gaby Deslys, exploring Hawaiian volcanoes with a noted geologist, getting tattooed with Jack London and losing himself in the Fiji Islands." 55 If Correthers's wagon and smock were not enough to mark his difference, then certainly his globe-trotting stories highlighted his otherness in bold.

Taylor similarly invoked dress as difference when she wondered "what the inhabitants of [Stone City] think of the invasion by these art students, who-dressed in smocks, overalls, riding 
breeches, pajamas and aprons - can be spotted any time during the day with their easels set up here and there on the hillside." 56 In this portrait, the village inhabitants were separated from the invading colonists explicitly by distance-artists atop the hill, locals in the valley - and implicitly by dress. In a slightly different vein, the St. Louis Dispatch, in its coverage of the colony, noted that the clothing of the artists was surprisingly not all that different from regular folks. "Grant Wood works in overalls," according to the Dispatch, "and the rest of the men wear quite nondescript clothes. The women also avoid the freakish and bizarre in attire. One girl goes about in shorts and another wears khaki trousers; the rest are satisfied with conservative skirts. Only one beret and smock were in evidence the other day, and there wasn't a Van Dyke beard on the place." 57 Regardless of whether or not the artists of the Stone City colony actually appeared any different than their neighbors in the village below, the point is that-like the heightened interest in the ice wagons - the concern with clothing on the part of journalists spoke to the understanding of the colony and its inhabitants as other, as odd, and as potentially queer.

While journalists used ice wagons and clothing as a way to articulate the otherness of the colony residents, they simultaneously suggested that Stone City's pastoral setting was the ideal place for that difference to reside. After a Cedar Rapids Gazette reporter visited Stone City in the spring of 1933, for example, the paper devoted an entire article to the colony's director, Adrian Dornbush, and his acquisition of a house in the village. Dornbush had been a longtime resident of Cedar Rapids and an instructor at Rowan's Little Gallery and was a friend and supporter of Wood. He was also openly homosexual. ${ }^{58}$ The Gazette omitted explicit mention of his homosexuality, but it implied as much when it described Dornbush as having an "artistic soul," a predisposition that served him well in refurbishing the abandoned house he shared with his male "cohort" Kelly Greenwell. Crucially, for the Gazette, that rundown structure located in Stone City's pastoral

56. Taylor, "Picturesque Stone City Given New Life."

57. "The Quarry Town that Came to Life Again." On this issue of dress at the Stone City colony, also see Evans, Grant Wood, 151.

58. Evans, Grant Wood, 151. 
setting was the "Ideal Home" for these queer men and their "menagerie" of animals, which included a blacksnake the couple had spared in their renovations and was, the paper suggestively noted, "beginning to accept . . . as one of the family." Echoing earlier Edenic portrayals of Stone City's Golden Age, the Gazette closed its feature on Dornbush by noting, "It seems as if [the artist] must have found paradise-complete even to the snake." 59 For the odd, the different, and the queer, then, the Stone City colony and its pastoral environs were the place to be. A place apart both spatially and temporally, the Stone City colony had the potential to safely harbor those who were other.

This is not to suggest - as other scholars have - that the Stone City colony was a space of heightened homosexual sex or romance. ${ }^{60}$ No documentation exists to support such a claim. But neither does evidence exist to suggest that there was any less sex - queer or otherwise-happening in Stone City than elsewhere at that time. Stone City was not a place where queer people like Wood went to "hide," to somehow "butch up" or otherwise invigorate their art with masculinity by going back to the land. ${ }^{61}$ Instead, to note the queerness of the pastoral space of Stone City - its spatial and temporal otherness - is simply to suggest that this was a space where queer people could exist, albeit temporarily, outside of dominant institutions, a space that was made safe for queer individuals. ${ }^{62}$

For artists like Wood, Dornbush, and others, Stone City was a sanctuary from demands such as marriage, the rearing of a family, and everything that came with heterosexual domesticity - elements of a "normal" life in which Wood seemed largely uninterested. Wood's bachelorhood was widely commented upon

59. All quoted material in the paragraph comes from "Artist Finds Ideal Home in Deserted Stone City House," Cedar Rapids Gazette, 6/11/1933.

60. Seery, "Grant Wood's Political Gothic."

61. Evans, Grant Wood, 151-56.

62. Queer studies scholar Henry Abelove, for example, suggests that pastoral narratives often highlight the value of, and call for, queer lives lived outside of heteronormative dictates of "domesticity, romantic love and marriage, and the white bourgeois family." Henry Abelove, "From Thoreau to Queer Politics," in Deep Gossip (Minneapolis, 2003). On rural space as queer safe space, see David Bell and Gill Valentine, "Queer Country: Rural Lesbian and Gay Lives," Journal of Rural Studies 11 (1995), 113-22. 
by journalists and others in the 1930s. Within the discourse of feigned ignorance, his long-lived bachelorhood decidedly signaled queerness, especially when combined with his close relationship with his mother, with whom he would live until her death in 1935. Wood often proclaimed that he would never marry while his mother was alive and under his care-this even though as a young man "Wood's own marriage prospects ... were as good as any young man's in Cedar Rapids." ${ }^{63}$ Likewise, Garwood noted that "plenty of girls would have liked to keep house for him, but Grant didn't follow up his opportunities." Wood was reported to have confided in a close friend, "I guess I'm just not that interested in women." 64 Wood's unmarried status seems to have been generally accepted by his friends and supporters, but the repeated references to his bachelorhood were surely a weighty reminder that, as an unwed artist sharing a studio with his widowed mother, he struck a rather-if tacitly accepted-queer figure.

In Stone City, however, Wood's marital status could fade into the background. Wood was well set in his bachelorhood-and already in his early forties - by the time of the Stone City colony. Nonetheless, the pressure was still there, and the colony of artists nestled in the pastoral landscape of Stone City allowed the artist to remove himself from the heteronormative demands of life in Cedar Rapids. At the margins of an industrialized world, Wood could take his place among like-minded individuals as shepherd of his artistic flock.

\section{Pastoral Possibilities Crumble in Iowa City}

Like most good things, the Stone City Art Colony and School was not to last. Financial difficulties, coupled with employment opportunities for Wood elsewhere, spelled the end of the colony experiment after only two summers. Despite Harlan Miller's proclamation that art at Stone City was the business of the soul, there

63. Evans, Grant Wood, 36-37.

64. Garwood, Artist in Iowa, 91. Garwood's biography was not an academic study and, as Kristy Raine has described it, tended at times to be rather "gossipy." Wood's sister, Nan Wood Graham, took particular issue with Garwood's portrayal of Wood as uninterested in women. Kristy Raine, e-mail message to author, 7/15/2014; Evans, Grant Wood, 300, 375. 
were still debts to be paid. The tuition and room and board collected from students fell far short of paying the colony's outstanding bills, and the colony ended its 1933 session in debt by almost $\$ 1,500.65$ Ultimately, with the help of a grant from the Carnegie Corporation - a grant originally meant for the colony's purchase of the Green estate in 1933 - and the personal wealth of one of Wood's friends, John C. Reid, the debts were eventually settled a year later. 66 The debts themselves, however, were not enough to sink the colony.

The death blow came during the winter of 1933-34, when Wood was persuaded by his mother and David Turner to accept a position as director of Iowa's Public Works of Art Project overseeing the completion of a set of murals at the Iowa State College of Agriculture and Mechanic Arts (now Iowa State University) in Ames. According to Wood's biographers, David Turner - at the behest of Wood's mother, Hattie - threatened to evict Wood from Five Turner Alley if he refused to give up the venture at Stone City, which, from a business perspective, was a failure. ${ }^{67}$ Later that year, as an offshoot of his PWAP work, Wood would also accept a position as a lecturer in the Department of Graphic and Plastic Arts at the University of Iowa and move with his mother from Cedar Rapids to Iowa City. ${ }^{68}$ The dreams of Stone City were now ghosts themselves, and Wood had exited the marginal, queer realm of freelance artists and entered the thoroughly bureaucratized and normative institutions of the state and federal government and academe.

As part of this major shift toward normative institutions, Wood did something that surprised everyone: he got married. In March 1935, as his mother's health began to fade following the move to Iowa City, Wood - just shy of 45 years old - married the

65 . The $\$ 1,500$ debt in 1933 would be equivalent to approximately $\$ 27,400$ in 2015. www.measuringworth.com/uscompare.

66. The colony's debts were fully paid sometime in the fall of 1934 . For details regarding the debts and their payments, see John C. Reid to Frederick P. Keppel, Carnegie Corporation, 7/23/1934; John C. Reid to Robert M. Lester, Carnegie Corporation, 7/31/1934; Robert M. Lester to John C. Reid, 8/6/1934; and John C. Reid to unknown, 9/11/1934, all in folder 2, box 1, John C. Reid Papers.

67. Garwood, Artist in Iowa, 162-63; Evans, Grant Wood, 165-67.

68. Walter A. Jessup (University of Iowa president) to Grant Wood, 1/1/1934, folder 3, box 6, Grant Wood Papers. 
singer, actress, and divorcée Sara Sherman Maxon. ${ }^{69}$ Announcing the nuptials, Wood's local paper, the Cedar Rapids Gazette, noted, "So busy have press and the public been, watching Grant Wood's meteoric rise to fame, they failed to sense the importance the past year of first signs of his digression from single-track bachelordom. [The attention of the press] was so far removed from the thought of romance as to make the culmination of this courtship a major surprise." 70 Surprise as it was, Wood's marriage, which was never a happy one and ended in divorce in 1939, brought Wood (even more fully than his academic position) into the mainstream and made the queer pastoral possibilities of Stone City seem like a lost dream.

This is not to say that Wood had given up on the Regionalist vision he had established at the Stone City colony. Wood's vision of a communal, Regionalist art movement persisted-only now it had gained the legitimacy of the state and academe and shifted landscapes from the hills of Stone City to the halls of the University of Iowa. In addition to the mural work Wood oversaw, he also held a series of art "clinics" at the university. Both activities were explicitly seen as outgrowths of Wood's time at Stone City. ${ }^{71}$ Wood also continued to call for the development of regional art centers, which he often compared to medieval cities competing over the construction of gothic cathedrals. ${ }^{72}$

As the Daily Iowan suggested, however, there were pitfalls to such an approach. "There is a danger in this, of course," the paper reported, "danger that hundreds of miniature Grant Woods will spring up. ${ }^{73}$ [Wood] himself recognized this and expressed

69. Evans, Grant Wood, 205.

70. "Grant Wood and Sara Sherman Maxon to Be Married Tonight in Minneapolis," Cedar Rapids Gazette, 3/2/1935.

71. See "Professor Wood Spreads the Gospel," Daily Iowan, 10/14/1934; "Grant Wood, Clinician - His Patients: Artists; His Operations: On Pictures!" Daily Iowan, 10/30/1934; "Grant Wood Helps Young Artists Develop Technique," Daily Iowan, 11/3/1935; “G. Wood Has Third Clinic," Daily Iowan, 11/16/1935.

72. Tom Yoseloff, "Grant Wood, Back from East, Has Plan for U.S. Financed Artists' Centers," Daily Iowan, undated, folder 1, box 1, Grant Wood Papers.

73. "Professor Wood Spreads the Gospel," Daily Iowan, 10/30/1934. For confirmation of this charge, see Breanne Robertson, "Politics in Paint: The Creation, Destruction, and Restoration of the Cedar Rapids Federal Courthouse Mural," Annals of Iowa 74 (2015), 263-313. 
it when he said recently that modern art will soon formulate rules and become more dogmatic and academic than the early academic art which it supplanted." 74 Wood was perhaps already sensing the ground shifting beneath his feet, as his Regionalist projects-developed at the Stone City colony-began to clash with the very academic and dogmatic elements of modern art he hoped would curtail simple imitation.

Wood and his clinics may have been popular with the public and students, but the newly minted professor quickly ran up against artists and academics in his own department at the University of Iowa who were less than happy with their well-known colleague. Wood was convinced that his colleagues - most notably the department chair, Lester Longman - were simply jealous of his popular appeal, but Longman and others charged that Wood lacked artistic ability and was a domineering teacher. Moreover, and perhaps most threateningly, they also implied that he was a homosexual. 75

The conflict came about in large part because the modern art world's dalliance with Regionalism had largely ended by the 1940s as newer schools of art, such as Abstract Expressionism, began to take hold. Abstract Expressionism was, in part, a reaction against the Regionalists, who were now seen as too insular, too populist, and far too similar to the growth of fascism in Europe. ${ }^{76}$ This development was largely anathema to Wood, who had grown famous disavowing abstraction in favor of realism, practice over theory, and the quotidian in lieu of the academic. Thus Wood, in the late 1930s and early 1940s, became the victim of a perfect storm. His art had suddenly ceased being fashionable among art critics, and his queerness, which earlier had often been nothing more than a humorous side note, had now become a serious liability and a source for potential blackmail.

One of the most remarkable things about that shift is the way the language around Wood's queerness changed. Where the

74. "Professor Wood Spreads the Gospel."

75. Joni L. Kinsey provides the most thorough overview of the Wood-Longman controversy. See, Kinsey, "Cultivating Iowa," 26-32.

76. See, for example, Lester Longman to George F. Kay (dean of the College of Liberal Arts), 12/9/1940, folder 4, box 6, Grant Wood Papers; and Evans, Grant Wood, 297. 
newspaper coverage of Stone City was rife with tacit acknowledgment-with feigned ignorance - the bureaucratic stylings of academe rendered the artist's queerness virtually silent in university correspondence. Many of the letters that circulated among Wood, Longman, their colleagues, university administrators, and outside parties survive, and they often speak to the "charges" leveled against Wood: that his paintings, with only a few exceptions, were not noteworthy; that his art was too illustrative; that he could not draw and relied on photography; that he made his students do most of his own work; and that he forced students to draw and paint like him. ${ }^{77}$ Only a few, however, speak to Longman's implied accusation of homosexuality, and when they do, they do so not through a rhetoric of feigned ignorance but through a discourse of shamed silence.

Longman, who was almost 20 years younger than Wood and academically trained in art history, first joined the University of Iowa art department in 1936. The feud between Wood and Longman simmered for several years before someone in the department leaked information about the ongoing conflict to Time magazine in 1940. As Joni Kinsey notes, the informant was most likely Fletcher Martin, the artist Longman handpicked to replace Wood while the latter was on sabbatical - a leave that university administrators granted in an effort to retain Wood and calm the departmental waters. Kinsey suggests, however, that Martin had been a member of the faculty for only a short while, "so most of his knowledge of Wood probably originated with Longman."78

With the litany of charges against Wood potentially going public (although Time never published the story), the debate came to a head, and the specter of Wood's queerness lurked furtively at the edges. In a letter to the dean of the College of Liberal Arts, for example, Longman lamented what he saw as Wood's very unacademic publicity machine, which included a live-in agent and-as Longman pointed out parenthetically - a Jewish sales promoter. "Wood himself prepares and promotes the high

77. For an overview of the controversy, including the list of "charges," see Dean George F. Kay's "Notes made in relation to conference in my office with regard to members of the staff of instruction of the Department of Art," folder 4, box 6, Grant Wood Papers.

78. Kinsey, “Cultivating Iowa,” 29. 
powered publicity campaign through a local agent who lives in his house," he wrote to his dean in December 1940, "as well as in conjunction with the leading (Jewish) art sales promoter in New York." 79 The publicity agent was Park Rinard, who indeed had moved into Wood's house following the artist's divorce and who acted as Wood's secretary, although the accusations clearly implied that the men cohabitated on more than a professional level. ${ }^{80}$

Although the charge of homosexuality was likely easily read into comments like these, it was - at least in the surviving documentation-never explicitly made. As art historian Joni Kinsey notes, the only extant documentation of the departmental crisis that explicitly used the term homosexual comes from a 1941 memo detailing a meeting that included Rinard, university president Virgil Hancher, and others. ${ }^{81}$ "Comment had been made," the memo reads, "on the 'strange relationship between Mr. Wood and his publicity agent,' an inference and intimation indicating that Grant Wood was a homosexual and that Park Rinard was involved." 82 Such explicit language, however, was the exception in this conflict. Gone, too, was the more relaxed and playful discourse seen at Stone City; silence was the order of the day in Iowa City.

With Longman's accusations - implied or otherwise-potentially going public, Wood threatened to resign. As a result, the university scrambled to retain its best-known artist. Rinard went to work as well, marshalling support from Wood's friends back in Cedar Rapids. In a letter to John C. Reid, who was now a member of the state board of education, which oversaw the state universities, Rinard signaled - through Wood's silence on the matter - that the controversy was more intense, and more personal, than an academic debate over painting techniques or artistic ability. Rinard wrote that the controversy was "a subject so close and so personal to Grant that it would be difficult for him to speak to you about it." 83 Indeed, when Wood did speak about it, he hinted

79. Lester Longman to Dean George F. Kay, 12/9/1940, folder 4, box 6, Grant Wood Papers.

80. Evans, Grant Wood, 275, 282.

81. Kinsey, "Cultivating Iowa," 29.

82. Notes of meeting with President Virgil Hancher, Park Rinard, and Dan Dutcher, 5/8/1941, folder 5, box 6, Grant Wood Papers.

83. Park Rinard to John C. Reid, 3/14/1941, folder 1, box 1, John C. Reid Papers. 
at similar, more intimate, attacks that went beyond departmental politics. In a letter to university president Virgil Hancher, Wood declared, "The matter of vindication ... extends beyond the university and crucially concerns my reputation as an artist and my personal character." 84

Reid echoed those sentiments, as well as the silence, when he came to Wood's defense. Previously, Reid had always portrayed the artist - with perhaps a touch of hyperbole - as "every inch a man and entirely free of the vices that usually go with men of his profession. He is wholesome, red blooded and a man's man from every standpoint." In letters to President Hancher regarding the departmental crisis, Reid similarly did not mince words when he characterized the infighting as "fantastic, unreal and neurotically childish." He urged President Hancher to either demote or fire Longman and warned of "the repugnance that would be felt by practically every fair-minded, intelligent person outside of the University, if the dastardly attack on Grant Wood were fully exposed to the people of the State." 85 For Reid, Rinard, and Wood, the conflict clearly went beyond professional matters of art and academics. Moreover, unlike during the years spent in Cedar Rapids and Stone City, feigned ignorance could not solve the conflict; silencing Longman was, for these men, the solution.

\section{Conclusion}

Ultimately, the conflict between Wood and Longman was never resolved - at least not in any satisfactory way. The university retained Longman as chair of the department and, rather than accepting Wood's resignation, offered him a year-long sabbatical. Wood returned to the university in the fall of 1941, only to discover that he was terminally ill. In February 1942 Wood died of pancreatic cancer at the University of Iowa hospital, with Park Rinard at his side. 86

84. Grant Wood to President Virgil Hancher, 6/18/1941, folder 3, box 1, John C. Reid Papers.

85. John C. Reid to Edward P. Schoentgen, 10/17/1933, folder 1, box 1, John C. Reid Papers; John C. Reid to President Virgil Hancher, 4/21/1941, ibid.; John C. Reid to President Virgil Hancher, 5/2/1941, ibid.

86. On Wood's diagnosis of pancreatic cancer (as opposed to liver cancer, which, before the reexamination of Wood's medical records in 1992, was thought to 
The years Wood spent in Iowa City were difficult ones. He was removed from his former base of support in Cedar Rapids and even further removed from the queer pastoral possibilities of Stone City. Moreover, as the art world shifted beneath Wood's feet during the late 1930s and early 1940s, the queerness that was widely acknowledged but easily deflected and ignored, especially in the pastoral space of Stone City, became a dangerous liability.

After doctors discovered his cancer late in 1941, Wood again tried to resign from the university. Once again, the resignation was rejected, this time out of respect as much as self-interest. Temporarily ignoring Longman's accusations, the university issued a press release upon Wood's death in February 1942, proclaiming the departed as "an original and creative artist of unusual talent who in his all too short life made a superb contribution of permanent value." 87 Like the ghosts of Stone City, however, Wood's contribution to twentieth-century American art was quickly relegated to the shadows.

Interest in Grant Wood's art and life, however, has never been higher than in recent decades. ${ }^{88}$ Yet outside of academic circles, the artist's queerness still largely remains an open secret. In many ways, that is fitting, as that was how Wood lived for most of his life. Given his last few years in Iowa City, however, there is some poetic justice in openly reclaiming Wood as a queer figure, in understanding not only how his queerness was reflected in and through his artwork, but also in articulating how his queerness was understood by those around him in various places and at various times. By more fully placing the queer figure of Wood within the history of his time at the Stone City Art Colony and School and at the University of Iowa, we are rewarded with a fuller, sharper, more defined picture of the artist's life-gay gypsy caravan and all.

have caused the artist's death), see Kinsey, "Cultivating Iowa," 31; and Evans, Grant Wood, 289. On Rinard's presence at Wood's deathbed, see Evans, Grant Wood, 292.

87. Grant Wood to Virgil M. Hancher, undated, folder 7, box 6, Grant Wood Papers; Earl E. Harper to Harry K. Newburn (Dean, College of Liberal Arts), 1/12/1942, folder 7, box 6, Grant Wood Papers; Eugene A. Gilmore, telegram to Pittsburgh Press-Citizen, 2/13/1942, folder 4, box 6, Grant Wood Papers.

88. On present-day adaptations of Wood's work, see Evans, Grant Wood, 8-9. 